At-Turats

Jurnal Pemikiran Pendidikan Islam

journal homepage: http://jurnaliainpontianak.or.id/index.php/atturats

\title{
Pelaksanaan Pembelajaran BCCT Bagi Anak Usia Dini; Study Pelaksanaan BCCT Di Tk Islam Mujahidin Pontianak
}

\author{
Nur Hamzah \\ Fakultas Tarbiyah dan Ilmu Keguruan (FTIK) \\ Institut Agama Islam Negeri (IAIN) Pontianak \\ hamzah_ptk@yahoo.com
}

\begin{abstract}
A B S T R A K
Nowadays, there are a lot of pre-school educational institution such as Kindergarten (TK), Raudhatul Atfhal (RA), Playgrounds, Children Care, Early Childhood Education (PAUD), and so forth. Furthermore, in these educational institution, study method and approach is developed based on earl childhood characters. One of the ways is named Beyond Centres and Circle Times (BCCT). Moreover, the BCCT is theoretically a study approach which is held at the centre or cirlce. The children apparently learn something based on their themes and centre. Besides, there are still few pre-school institutions performed this model on their schools because it provides more human resources, spaces, and budget. In Pontianak, some schools have applied this method, and one of them is TK Islam Mujahidin.
\end{abstract}

Key words: BCCT, Early Childhood

\section{LATAR BELAKANG}

Pendidikan bagi anak di usia dini dalam banyak kajian akademik sangat urgen. Dikatakan urgen karena ia akan menjadi fundamen bagi pembentukkan dan pengembangan segala potensi yang dimiliki manusia. Individu bahkan menurut Kholberg dapat diramal karakteristik sosialnya pada usia remaja sejak ia usia 5-8 tahun. Jika anak pada usia 5-8 tahun mengalami masa sulit dalam pengembangan sosialnya entah karena disebabkan konflik sosial, perang atau keluarga yang broken, maka pada saat usia remaja, mereka akan menjadi individu anti sosial (Kholberg dalam Nugraha, 58, Tanpa tahun). Begitu pula pada aspek pengembangan lain sebagaimana yang dirumuskan Gardner tentang 8 kecerdasan jamak manusia. Semua kecerdasan tersebut menghendaki pembentu- kannya sejak usia dini yakni 0-8 tahun.

Urgensitas pendidikan pada usia ini dikarenakan pada anak usia 0-8 tahun adalah usia dimana segala bentuk pengalaman yang diterima anak akan membekas lama. Ditambah lagi bahwa pada usia ini segala macam aspek potensial manusia tumbuh dan berkembang begitu cepat. Perkembangan itu meliputi perkembangan fisik, kognitif, sosial dan mental. Karena keistimewaan inilah maka masa usia 0-8 tahun disebut oleh para ahli dengan periode emas (Golden Period). Disebut periode emas karena pada masa ini anak sangat peka terhadap segala macam rangsangan dan stimulus dari luar yang datang kepadanya. Bayangkan saja, otak anak umur 8 tahun telah mencapai $90 \%$ volume otak orang dewasa, dengan demikian untuk umur selanjutnya tinggal menambah $20 \%$ saja 
(Hamzah.3.2015). Demikian pula pada aspek perkembangan lainnya.

Pada zaman sekarang, karena melihat begitu pentingnya pendidikan di usia dini maka banyak didirikan lembaga pendidikan pra-sekolah. Di Indonesia lembaga pendidikan pra-sekolah mengambil bentuk Taman Kanak-kanak (TK), Raudhatul Atfhal (RA), Taman Bermain, Tempat Penitipan Anak, Pendidikan Anak Usia Dini (selanjutnya disingkat PAUD) dan lain sebagainya. Dalam lembaga pendidikan ini selanjutnya dikembangkanlah beragam pedekatan dan metode pembelajaran yang sesuai dengan karakteristik anak usia dini. Beberapa model pembelajaran tersebut misalnya: pendekatan belajar Frobel, konsep belajar Hill, Model Montesory dan termasuk model Beyond Centres and Circle Times (selanjutnya disingkat BCCT). Untuk diketahui bahwa masing-masing model pembelajaran ini memiliki kelebihan dan kelemahan sendiri-sendiri. Oleh sebab itu pilihan sebuah lembaga pendidikan terhadap model pembelajaran ini berdasarkan pertimbangan akademik, kebutuhan dan karakteristik subyektif.

Di Indonesia, tidak banyak lembaga pendidikan pra-sekolah menggunakan model BCCT dikarenakan ketidaksiapan SDM dan kekurangan dukungan finansial. Khusus di Pontianak misalkan, berdasarkan data yang penulis dapat, dari 38 lembaga pendidikan pra-sekolah, hanya ada 4 (empat) sekolah yang menggunakan model BCCT yaitu: Taman Kanak-kanak Islam Mujahidin 1 dan 2, Taman Kanak-kanak Al-Kautsar dan Taman Kanak-kanak Islam Az-Azhar. Padahal, jika model ini diterapkan, banyak kelebihan dan manfaat yang diterima oleh anak usia dini untuk memaksinalkan potensi yang dimilikinya.

Pendekatan BCCT secara teoritik dapat dimaknai sebagai pembelajaran yang diselenggarakan pada sentra dan lingkaran. Di sentra anak belajar sesuai tema dan sentranya. Anak diberikan aturan bermain saat berada dalam sentra sambil guru mendampingi dan mencatat seluruh kegiatan siswa. Dan terakhir guru meminta anak membereskan mainannya sekaligus menyuruh mereka menceritakan pengalaman saat berada di sentra. Anak pada kegiatan ini mengkonstruk pengetahuan dan pengalamannya sendiri karena aktvitas yang mereka lakukan.

Terdapat beberapa sentra biasanya yang ada di TK/RA yaitu sentra balok, pasir, air, rumah, rumah ibadah, dapur, seni dan lain sebagainya. Karena terdapat beberapa sentra, maka pendekatan ini dilaksanakan kegiatan moving class, dimana anak berpindah dari satu sentra ke sentra lain dalam melakukan pembelajaran. Karena konsep moving class inilah maka anak menjadi tidak bosan sebab menghadapi situasi kelas yang selalu berbeda. Inilah sedikit manfaat model BCCT, yang pada lembar kerja berikutnya akan penulis paparkan lebih rinci.

\section{SEKILAS TENTANG AUD}

Para pakar dalam mendifinisikan dan membuat batasan tentang anak usia masih belum satu kesepakatan. Di Indonesia, batasan umur anak usia dini adalah 0-6 tahun, sehingga pada usia 7 tahun anak telah dikatakan siap melaksanakan studi pada jenjang pendidikan dasar. Namun di banyak negara dan difinisi umum yang dikemukakan oleh NAEYC (National Association Education for Young Children) bahwa anak usia dini adalah sekelompok individu yang berada pada rentang usia antara 0-8 tahun. Berikutnya berdasarkan batasan ini, anak usia dini dikelompokkan menjadi: 1) kelompok bayi yakni umur 0-12 bulan; 2) kelompok bermain yakni umur 1-3 tahun; 3) kelompok pra-sekolah 
yakni umur 4-5 tahun dan; 4) kelompok usia sekolah berada pada umur 6-8 tahun (Hartati; 2005, 8).

Sebagai individu, anak usia dini tentu memiliki karakteristik perkembangan dan hal tersebutlah yang membedakannya dengan individu lainnya. Beberapa karakteristik tersebut dirangkum menurut beberapa ahli psikologi adalah sebagai berikut:

a. Anak usia dini memiliki sifat egosentris yang tinggi. Anak cendrung melakukan, melihat dan menilai dari sudut pandang mereka sendiri. Penilaian, moral dan subjektifitas masih sangat kental menguasai emosi mereka. Sifat egosentrisme biasanya muncul pada kehendak anak yang mesti terwujud. Anak kadang pada saat menginginkan sesuatu maka dengan cara apapun akan dilakukannya, termasuk meminta orang dewasa yang melaksanakannya. Jika yang menjadi kehendak anak tidak terpenuhi maka anak akan berontak dengan menangis, teriak, marah dan lain-lain. Agar egosentrisme ini tereliminir pada usia lanjut mereka, maka orang dewasa harus melakukan intervensi melalui pendidikan dan pengajaran (Hamzah,2015,2).

b. Anak memiliki rasa ingin tahu yang begitu besar dan dalam. Apa saja yang dilihat, didengar, dirasakan dan dialami oleh anak, akan menyebabkan mereka menelisik terhadap hal tersebut. Mereka akan berusaha mencari tahu secara detail tentang kejadian tersebut yakni apa, mengapa dan bagaimana. Dari sinilah kemudian terjadi proses trial and error. Anak selalu berusaha menjelajahi dunia sekitar mereka dan berinteraksi dengan hal tersebut. Untuk memenuhi rasa ingin tahu, anak sering mengajukan banyak pertanyaan dan tak jarang orang dewasa tidak mampu menjawab pertanyaan tersebut (Ibid,2015,3). c. Anak memiliki daya imaginasi dan fantasi yang sangat tinggi. Bagi seorang anak, sebuah balok kayu dapat menjadi sebuah pesawat terbang, mobil atau rumah. Benda mati dibuat seolah bernyawa dan hidup. Dengan boneka anak dapat bermain, berinteraksi dan berdialog. Dengan benda pula kadang anak mengekspresikan emosinya seperti suka, senang, marah, sedih dan lain-lain.

d. Anak adalah Pebelajar Ulung. Usia AUD adalah usia dimana proses perkembangan baik fisik, kognitif, sosia-emosional, moral, bahasa, dan motorik sangat drastis dan cepat. Contoh saja perkembangan sel otak, pada usia pra-natal setiap menit sel otak akan tumbuh sebanyak $250 \mathrm{sel}$, sehingga pada saat kelahiran anak telah memiliki milyaran. Berikutnya saat lahir, bayi memiliki 25\% berat otak orang dewasa, usia 3-4 tahun telah ada 75\%, dan ketika usia 5-6 tahun $90 \%$ otak anak dari otak orang dewasa. Sedemikian cepatnya perkembangan fisik, demikian pula perkembangan belajar AUD. AUD dikenal sebagai individu pebelajar ulung karena kemampuannya dalam menyerap, menguasai dan menerapkan pembelajaran. Contoh saja dari aspek penguasaan bahasa. Umur 1 tahun anak sudah mengusai 40 kata dan beberapa bulan kemudian menjadi ratusan. Menurut Tompkins bahwa kosakata anak akan bertambah sebanyak 3000 pertahun. Terhadap hal ini, bandingkan dengan perolehan belajar pada kita orang dewasa (Hamzah, 2015,3).

e. Ciri Emosi; Kaitan dengan emosi anak usia dini, menurut Hurlock eskpresi emosi muncul secara beragam pada diri anak seperti kasih sayang, gembira, sedih, takut, iri hati dan amarah. Emosi kasih sayang dimunculkan oleh anak saat ia berusaha 
menyayangi kedua orang tuanya, saudara atau orang lain yang ia telah kenal. Emosi kasih sayang juga muncul pada binatang kesayangan atau benda-benda lain milikinya seperti boneka, atau mainan lain. Kasih sayang diungkapkan melalui perilaku seperti memeluk, mencium, meminta gendong atau menggendong, ingin selalu bersama, tidak mau terpisah dan lain sebagainya. Kebalikan dari rasa sayang adalah amarah. Emosi amarah anak biasanya diungkapkan melalui memukul orang atau benda, melempar, berteriak, menangis, merajuk, tidak mau disentuh, menggertak dan lain-lain. Sementara beberapa hal yang dapat membuat anak marah yaitu apabila keinginannya tidak terpenuhi, tidak terpuaskan hasratnya seperti makan atau minum belum kenyang, mainan yang dimilikinya rusak dan lain sebagainya. Emosi berikutnya adalah iri hati. Iri hati pada anak dapat disebabkan karena anak hendak memiliki barang yang bukan milikinya apakah itu mainan atau benda lain yang kadang tidak ada hubungannya dengan yang ia butuhkan tetapi karena barang tersebut berada pada orang lain maka ia menghendakinya. Wujud dari emosi iri hati ini anak akan meminta kepada orang tua untuk mengambilkan benda tersebut, mengeluhkan bahwa benda atau mainannya tidak bagus, atau bahkan yang paling ekstrim adalah mengambil secara paksa benda tersebut. Pada kasus ini sesungguhnya yang terjadi bukan anak ingin memiliki benda sepenuhnya melainkan ia tidak rela jika benda tersebut berada pada anak lain. Selain karena sebab hendak memiliki ben$\mathrm{da}$, iri hati seorang anak juga dapat muncul karena kemampuan yang ia miliki tidak sama sebagaimana anak lain, misalkan selalu kalah dalam permainan yang mel- ibatkan banyak orang. Emosi yang berikutnya adalah gembira. Pada saat gembira anak akan tertawa, tersenyum, sumringah, semangat, bertepuk tangan, meloncat, berlari, berteriak girang dan lain-lain. Hal-hal yang dapat menimbulkan emosi gembira diantaranya: anak mendapatkan mainan baru, baju baru, buku baru dan lain-lain, dapat menyelesaikan satu pekerjaan, sedang menonton atau menyaksikan tayangan favorite, mendapatkan makanan kesukaan, sedang melakukan aktvitas kesenangan atau hoby dan yang pasti adalah pada saat bermain. Kebalikan emosi gembira adalah emosi sedih. Saat sedih anak akan ungkapkan dengan menangis, tidak semangat, cemberut, atau bahkan tidak mau melakukan aktvitas rutin seperti makan, ke sekolah atau bermain sekalipun. Terhadap beberapa ungkapan emosi ini, orang dewasa tidak perlu terlalu khawatir karena sebagaimana yang dituliskan oleh Goelman bahwa diantara ciri emosi pada anak usia dini adalah bahwa ia bersifat sementara alias tidak menetap, cepat berubah dari satu emosi ke emosi berikutnya dan tidak selamanya demikian. Walaupun demikian, orang dewasa niscaya mengawal dan mengarahkan pada emosi positif.

f. Ciri yang lain adalah bahwa AUD merupakan individu penjelajah. Segala hal selalu mengundang rasa ingin tahu mereka, oleh sebab itu untuk memenuhi rasa ingin tahunya ini ia senantiasa menanyakan kepada orang dewasa yang ada disekitarnya. Pertanyaan kadang sederhana, tetapi sering kali juga sangat radikal tentang apa, mengapa dan bagaimana. Begitu radikalnya, banyak orang dewasa tidak mampu menjawab pertanyaan anak tersebut. Pertanyaan biasanya oleh anak diulang berkali-kali sehingga hasrat ingin tahu mereka terpuaskan. 


\section{MODEL BCCT}

Terdapat dua jenis pendekatan dalam pembelajaran AUD, yaitu: (1) pendekatan pembelajaran yang berorientasi atau berpusat pada siswa (student centered approach) dan (2) pendekatan pembelajaran yang berorientasi atau berpusat pada guru (teacher centered approach). Dari dua pendekatan ini, berikutnya lahir berbagai macam model dan metode pembelajaran, semisal model belajar Frobel, konsep belajar Hill, Model Montesory, metode lingkari kalender, presentasi dan cerita, proyek sederhana, kerja kelompok besar, kunjungan dan lain sebagainya termasuk model Beyond Centre and Circle Time (BCCT).

Model BCCT atau sentra ini proses pembelajarannya berpusat di sentra main dan saat dalam lingkaran. Sesaat sebelum anak bermain, anak oleh guru diklasikalkan dalam bentuk melingkar mengelilingi guru. Ia bisa dilakukan dengan duduk ditikar atau duduk di kursi. Dalam posisi lingkaran inilah guru melakukan kegiatan pendahuluan pembelajaran. Pembelajaran dibuka dengan salam, mengabsen, menanyakan kabar anak, berdo'a, menyampaikan tema pembelajaran dan tujuan pembelajaran. Kegiatan ini dilakukan secara menyenangkan karna diselingi dengan lagu, gerak tari atau senam, tepukan dan lainlain. Kegiatan dalam lingkran juga dilakukan ketika penutupan pembelajaran, dimana guru melakukan recalling, memotivasi, melakukan penguatan dan do'a.

Selain pembelajaran dalam lingkaran, substansi BCCT adalah saat anak dalam area bermain. Dalam area bermain, sentra harus memenuhi 3 jenis main yang dapat mengakomodasi seluruh perkembangan anak. Ketiga kelompok main tersebut yakni (1). Main sensorimotor atau fungsional, (2). Main peran, dan (3) main pembangunan.

\section{PROSEDUR PELAKSANAAN BCCT}

Berikut penulis uraikan prosedur pelaksanaan model BCCT dalam pembelajaran sebagaimana hasil observasi yang dilakukan di TK Islam Mujahidin 1 Pontianak. Namun sebelum itu, penulis terlebih dahulu akan paparkan kondisi sarana dan media pembelajaran yang tersedia sebagai penunjang utama pelaksanaan pembelajaran BCCT.

\section{1) Kondisi Sarana Sentra Persiapan}

Sentra persiapan adalah area untuk anak meningkatkan kemampuan kognitif, pengatahuan, dan sains sederhana. Pada area ini anak bermain dengan angka, menghitung, menjumlah, mengurang, percobaan ilmiah sederhana seperti mengelompokkan warna, mencampur warna, bermain geometri, mencocokkan dan lain sebagainya.

Berdasarkan hasil wawancara dan obsevasi, maka sarana yang harus disiapkan pada sentra ini meliputi: pensil, spidol, tikar spon, kubus angka, macam-macam puzzle, gambar angka, gambar huruf, ABACUS, sempoa angka domino, tangga kubus, kubus angka, kubus huruf, puzzle geometri, puzzle angka, puzzle cat, puzzle benda, jam, pohon hitung, papan angka puluhan, boneka tangan, maket pakaian adat, tikar spon, menyanyam, crayon, lem, kertas origami, spidol, buku gambar dan lain sebagainya.

\section{2) Sentra Ibadah}

Sentra ibadah adalah salah satu sudut dimana anak diajarkan materi tentang ibadah dengan segala variannya, dengan tujuan untuk mengembangkan secara maksimal kecerdasan moral-spiritual anak. Dengan kecerdasan spiritualnya anak diharapkan sampai kepada pemahaman akan Tuhan sebagai Kuasa dan Pencipta. Dengan kecerdasan spiritual pula diharapkan anak dapat mengembangkan perilaku agamis dalam kehidupan sehari-hari. 
Mainan yang tersedia pada sentra ini meliputi: gambar masjid, gambar ka'bah, gambar orang sedang sholat, gambar orang berwudhu, gambar huruf hi'jaiyah, kaligrafi, pohon hijaiyah, beraneka puzzle dan masih banyak yang lainnya lagi.
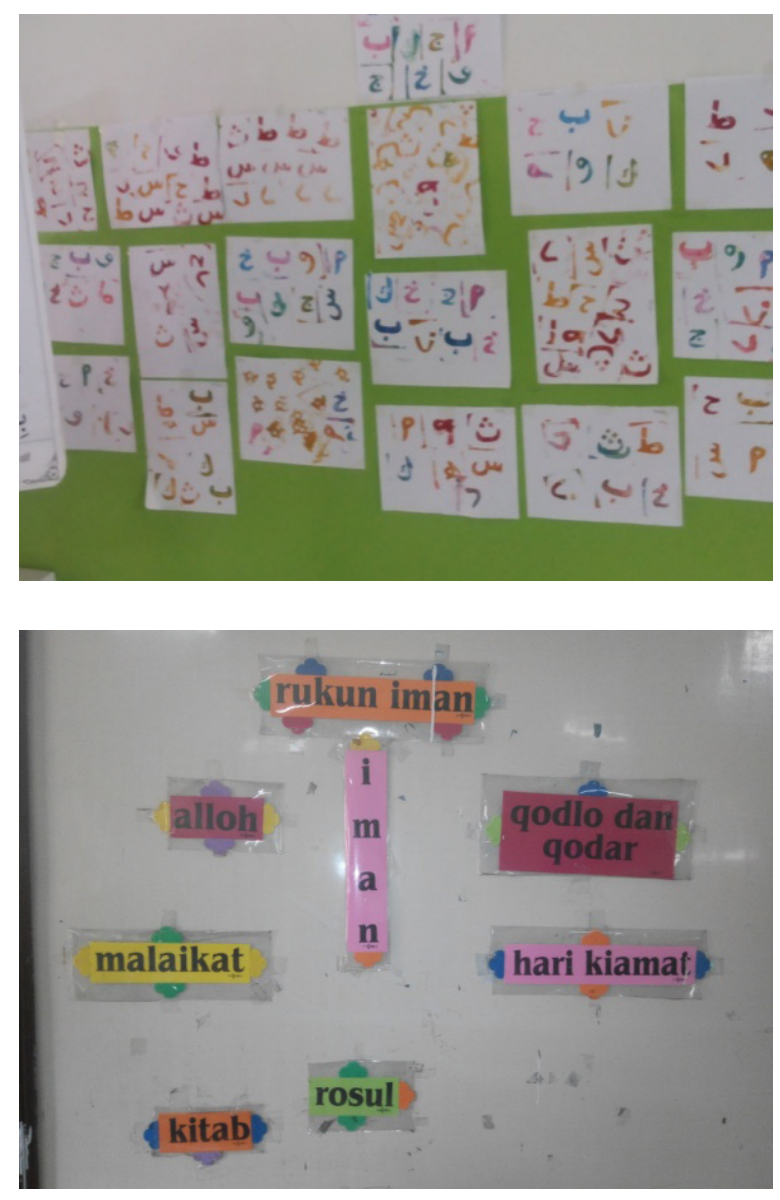

Gambar: Salah satu media yang terdapat dalam sentra ibadah

\section{3) Sarana Sentra Alam}

Sentra alam adalah satu sudut belajar yang dalamnya terdapat bahan-bahan alam baik benda hidup maupun benda alam mati. Tujuan sentra alam adalah agar anak dapat mengembangkan kecerdasan naturalistik atau lingkungan. Tidak hanya itu, area ini juga sangat berguna untuk mengasah kemampuan kognitif anak dengan percobaan sains sederhananya, kecerdasan matematika dan kecer- dasan motorik halus anank. Berdasarkan hasil observasi peneliti bahwa sarana yang tersedia pada sentra alam ini meliputi: biji-bijian, pasir, air, tanah, tepung, daun, kayu, pewarna, crayon, kuas, botol dan lain sebagainya.

Adapun kegiatan pembelajaran yang biasa dilakukan pada sentra ini yaitu: finger painting, colase, play doh, melukis, memancing ikan, mennggunting, menggoreng, mengayak, mencampur warna, memasukkan biji-bijian dalam wadah dan masih banyak lagi. Sebagaimana hasil pengamatan, bahwa kondisi sarana dan mainan yang tersedia pada sentra ini sangat baik, lagi pula karna memang bahan yang tersedia cukup banyak dan mudah didapat di alam.
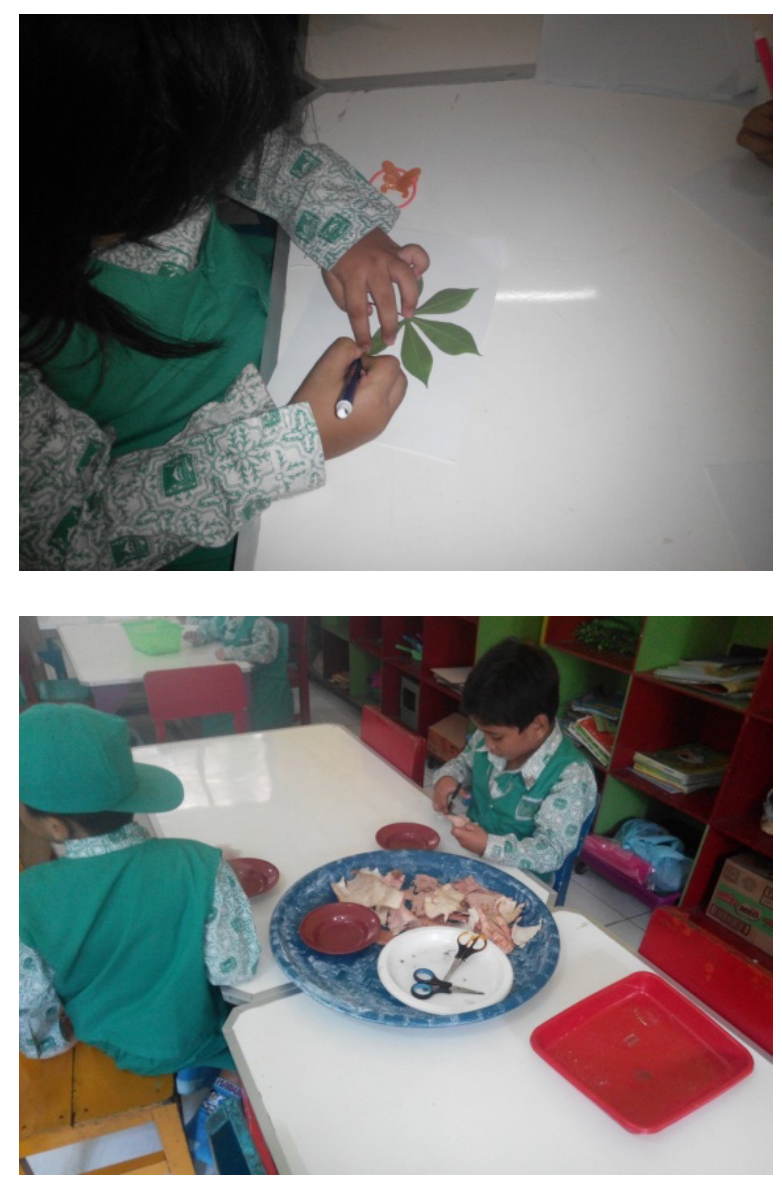

Gambar: anak sedang menggunting kulit singkong dan mencetak di sentra bahan alam 


\section{4) Sarana Sentra Bermain Peran}

Sentra bermain peran adalah sentra dimana anak diajarkan tentang peran mikro semisal profesi sebagai polisi, tentara, pemadam kebakaran, guru, penjual, kasir, dokter, perawat dan lain sebagainya. Pada area ini anak diminta memerankan profesi tersebut sesuai dengan tema yang diangkat pada saat pembelajaran tersebut. Semisal tema tentang kesehatan, maka anak dibagi perannya sebagai pembaca antrian, apoteker, perawat, pasien dan demikian selanjutnya pada tema yang berbeda.

Adapun tujuan dari area bermain peran ini adalah untuk melatih anak mengembangkan kemampuan bahasanya, berkomunikasi sesuai dengan peran yang dimainkan, memainkan peran, melatih kemampuan mendengar, menggunakan alat-alat yang digunakan, melatih kepercayaan diri, menumbuhkan minat terhadap satu profesi, menumbuhkan bakat dan cita-cita.

Sama halnya dengan sentra-sentra lain, beberapa alat yang tersedia pada area ini yaitu karpet, lemari atau rak tempat menyimpan mainan, papan tulis, kursi, meja dan alatalat mainan sesuai dengan tema. Berdasarkan hasil observasi beberapa sarana yang tersedia pada area ini seperti baju dokter, baju polisi, baju tentara dan beberapa mainan pelengkap. Pada saat observasi, hari itu tema yang diajarkan guru kepada anak adalah kesehatan. Alat permainan yang disiapkan oleh guru meliputi meja obat, kursi antrian, kartu antrian, obat, stateskop dan lain-lain. Tentang kondisi sarana pada area ini, terlihat semuanya baik.

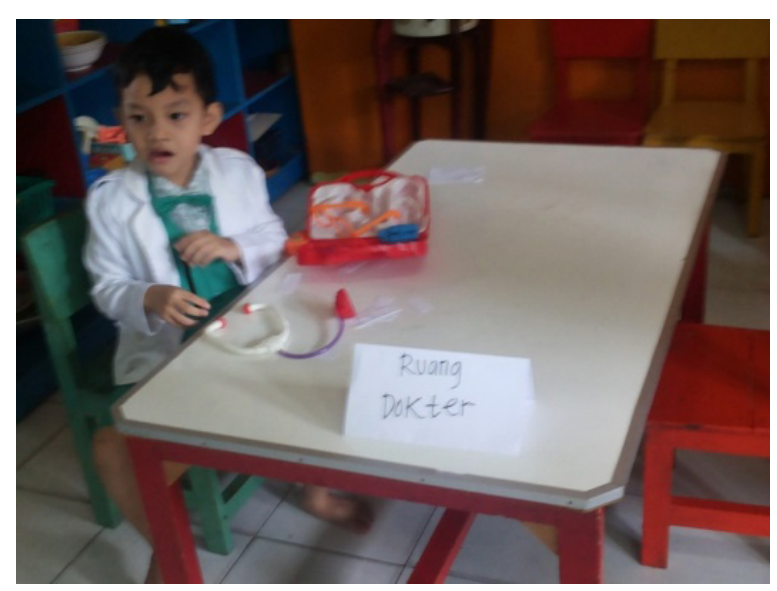

Gambar: Aktivitas anak ketika memerankan sebagai dokter

\section{5) Sarana Sentra Seni \& Kreativitas}

Pada sentra ini, anak diajak untuk bermain dan belajar tentang alat musik, bunyi, menggambar, menganyam, membuat adonan, membuat bentuk dari adonan, menggunting bentuk, menjahit dan lain sebagainya. Dalam pembelajaran dengan tema musik, anak diajarkan mengenai bentuk-bentuk alat musik, mulai dari alat musik tiup, pukul, petik, tekan (piano), dan gesek. Tidak sampai disitu, mereka juga belajar mengenai bunyi alat musik dan cara sederhana memainkan alat musik. termasuk yang diajarkan oleh guru juga adalah tentang irama. Pada tema ini, secara khusus aspek pengembangan yang dimunculkan yaitu pengembangan motorik halus dan aspek kecerdasan musikal. Walaupun demikian aspek lain seperti pengembangan bahasa, kognitif dan emosional juga sekaligus disentuh.

Untuk mendukung pembelajaran pada sentra ini, berdasarkan hasil observasi bahwa sarana yang tersedia pada sentra seni dan kreativitas meliputi: alat musik mainan seperti gitar, gendang, rebana, kerekan, suling, harmonika, angklung, terompet, piano, aneka jenis puzzle, crayon, buku gambar, pensil, gunting, dan masih banyak lagi yang lainnya. 


\section{6) Sarana Sentra Balok}

Sentra balok adalah sudut dimana anak belajar tentang geometri, bangunan, matematika sederhana, konsep kesimbangan bangunan, bentuk bangunan dan termasuk warna. Tujuan dari sentra ini adalah untuk mengembangkan kecerdasan visual-spasial anak agar dapat mengenali dan membedakan bangun ruang, termasuk dapat membantu mengembangkan kecerdasan matematika anak karena geometri adalah salah satu dasar dari matematika.

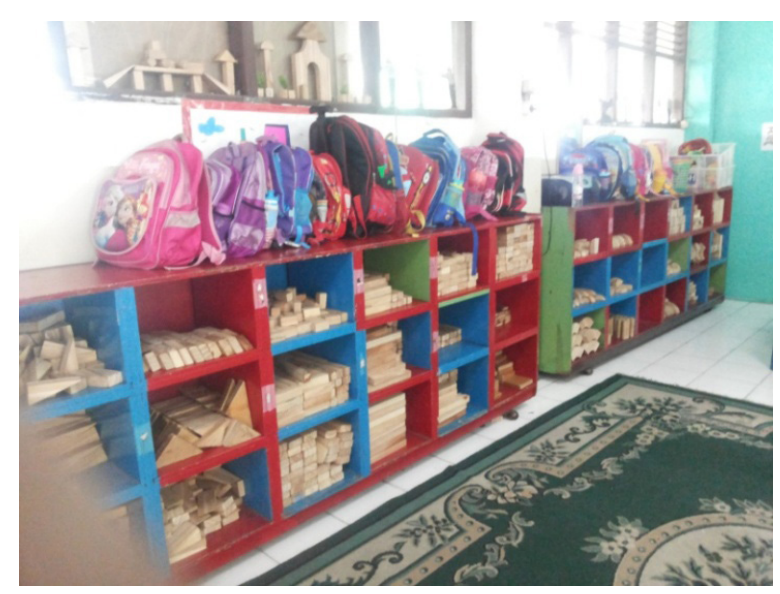

Gambar: Lemari Balok

Berdasarkan hasil observasi penulis bahwa sarana yang tersedia pada sentra balok ini meliputi balok susun natural, balok susun stoples, balok susun besar, balok susun kecil, menara segi enam, menara segi tiga, balok tangga warna, rambu lalu lintas dan lain-lain. Sementara hasil wawancara dengan guru, bahwa mainan yang tersedia pada area balok diantaranya berbagai jenis mainan balok, gambar-gambar, puzzle dan lain sebagainya.

Selanjutnya tentang prosedur pembelajaran dengan model BCCT dapat digambarkan sebagai berikut. Pembelajaran dengan model BCCT mengunakan empat langkah pijakan untuk mencapai mutu pengalaman main yaitu; 1). Pijakan lingkungan Main,
2).Pijakan pengalaman Sebelum main, 3). Pijakan pengalaman saat main, 4). Pijakan pengalaman setelah main.

\section{a. Pijakan Lingkungan}

Secara sederhana pijakan lingkungan adalah aktivitas guru mempersiapkan kondisi, tempat, peralatan, administrasi dan lain-lain sebelum dilakukan permainan pada sentra. Lingkungan bermain disiapkan dengan mengelar 'karpet atau kursi untuk kegiatan bermain. Kegiatan ini dapat dilakukan diluar atau di dalam ruangan. Secara teoritik lingkungan bermain yang bermutu adalah lingkungan main mendukung tiga jenis main yakni: sensorimotor atau main fungsional, main peran (makro/mikro) dan main pembangunan (sifat cair.bahan alam\&terstruktur).

Berdasarkan hasil observasi dan wawancara pada langkah awal pendekatan BCCT, beberapa hal yang dilakukan oleh guru yaitu guru menyiapkan tempat dan alat permainan sesuai dengan tema, memilih jenis permainan, cerita, lagu dan gerak serta merencanakan waktu pembelajaran. Adapun persiapan administratif yang dilakukan guru yakni menyiapkan catatan obsevasi, catatan perkembangan anak (bahasa, sosial-emosional, kognitif, dan moral-spiritual).

\section{b. Pijakan Pengalaman Sebelum Main}

Kegiatan pijakan sebelum bermain dapat juga disebut sebagai kegiatan pembukaan. Tujuan dari kegiatan ini adalah menyiapkan kondisi awal baik mental maupun fisik anak sebelum masuk pada kegiatan inti pembelajaran. Kegiatan pembukaan dilakukan dengan cara membentuk lingkaran kecil antara pendidik dan anak. Jumlah satu rombongan belajar paling maksimal 20 anak.

Sebagaimana halnya kegiatan pembukaan pada pembelajaran disekolah yaitu 
mengucapkan salam, doa, mengabsen kehadiran siswa, menyampaikan tema pembelajaran, melakukan apersepsi, menyampaikan tujuan pembelajaran dan memberikan motivasi awal, dalam kegiatan pembukaan di taman kanak-kanak juga demikian.

Berdasarkan hasil observasi, prosedur kegiatan pijakan sebeleum bermain telah dilakukan oleh guru di TK Mujahidin 1 Pontianak. Secara sangat rinci dapat digambarkan sebagai berikut:

1. Anak berbaris rapi untuk memasuki sentra, berikutnya mengucapkan salam kepada guru, dan sambil menyalami guru anak secara tertib memasuki sentra. Pada kegiatan ini anak diajarkan untuk berlaku disiplin, tertib, antri, sopan dan menghormati guru. Pada ranah ini maknanya guru telah melakukan pengembangan aspek moral-spiritual dan sosial-emosional anak.

2. Sesaat anak telah berada pada sentra, guru mempersilakan anak duduk melingkar diatas karpet. Selanjutnya guru mulai membuka pembelajaran dengan mengucapkan salam kepada anak, menanyakan kabar, menanyakan anak yang tidak masuk sekolah (mengabsen), berdoa, secara bersama-sama berikrar anak sholeh, bernyanyi dan bertepuk tangan. Kegiatan doa dan menanyakan kabar anak merupakan kegiatan untuk mengembangkan aspek spiritual dan sosial anak. Sementara kegiatan bernyanyi dan bertepuk tangan adalah kegiatan untuk mengembangkan aspek kognitif, aspek bahasa, aspek emosional dan motorik. Kegiatan yang dibuka dengan bernyanyi juga bertepuk tangan adalah kegiatan yang sangat menyenangkan bagi anak, karena memang demikian karakteristik psikologis mereka. Kondisi psikologis awal yang menyenangkan akan menjadi pra-kondisi kesiapan belajar anak pada tahapan berikutnya.

3. Kegiatan berikutnya adalah guru menyampaikan tema pembelajaran yakni menabung. Kegiatan ini tujuannya adalah agar anak mengetahui apa yang akan mereka pelajari dan alami pada satu hari kegiatan pembelajaran.

4. Setelah menyampaikan tema, guru bercerita tentang tema (menabung) dengan menggunakan media gambar tampak depan bank dan beberapa sudut tampak dalam bank. Guru menceritakan uang yang harus dihemat penggunaanya, menabung adalah perilaku baik, menabung dapat dilakukan di bank, dan tata cara menabung dibank. Pada kegiatan ini guru mengaitkan isi cerita dengan konteks kehidupan sehari-hari anak, termasuk memberikan penguatan sikap dan perilaku positif/negatif yang harus dilakukan/dihindari anak. Pada kegiatan ini juga guru mengenalkan anak pada istilah/kosakata baru seperti bank, buku tabungan, teller, costumer service dan lain-lain. Pada kegiatan ini guru juga menyelinginya dengan nyanyian dan tepukan. Pada kegiatan ini hampir semua aspek dikembang, mulai dari aspek kognitif, bahasa, sosial-emosional, moral-spiritual termasuk fisik motorik anak. Aspek bahasa, kognitif dan sosial-emosional dikembangkan melalui kegiatan bercerita, sementara aspek motorik baik kasar maupun halus dikembangkan dengan kegiatan nyanyian dan tepukan.

5. Langkah selanjutnya menyampaikan kegiatan pembelajaran dan permainan yang akan dilakukan dalam hal ini adalah peran mikro bank. Pada kegiatan ini guru menjelaskan tentang permainan, alat permainan yang akan digunakan dan cara menggunakan mainan.

6. Kegiatan berikutnya, guru menjelaskan 
tata aturan permainan dan lama waktu dalam bermain;

7. Selanjutnya guru menunjuk anak untuk memainkan peran, sebagai nasabah, teller, costumer service, securty dan pembagi kartu antrian.

8. Kegiatan terakhir kegiatan transisi dimana anak diminta siap untuk bermain. Pada kegiatan transisi ini ada waktu sekitar 15 menit dimana guru mempersilakan anak untuk mempersiapkan diri, ke toilet dan lain sebagainya.

\section{c. Pijakan Saat Bermain}

Kegiatan pijakan saat bermain adalah kegiatan inti pembelajaran. Pada kegiatan ini anak memainkan peran sesuai dengan sentra yang ia masuki. Mereka berbagi peran dalam permainan dan saling bergantian saat permainan. Jika misalnya satu permainan hanya untuk 5-10 orang, maka sisa anak bermain pada tema lain pada satu sentra yang sama. Setelah selesai satu permainan, maka anak digilir untuk memainkan peran baru.

Pada pijakan ini, posisi guru hanya sebagai fasilitator yang mengarahkan dan mengatur permainan. Waktu yang diperlukan untuk kegiatan ini paling sedikit 60 Menit. Ada banyak manfaat kegiatan ini diantaranya memberikan pengalaman baru, mengembangkan kemampuan komunikasi, meningkatkan penguasaan kosakata, mengembangkan daya imaginasi, memperkaya daya kreatif dan yang paling penting adalah menumbuhkan kemampuan bersosialisasi.

Pada kegiatan main ini berdasarkan hasil observasi penulis pada sentra peran mikro, beberapa hal yang dilakukan oleh guru TK Mujahidin Pontianak meliputi:

1. Guru mengatur, mengarahkan dan membimbing anak terhadap bermain peran yang mereka lakukan. Kegiatan ini dimaksudkan untuk mengawasi anak, membantu apabila anak menemui kesulitan dalam kegiatan bermain mereka.

2. Hal lain yang dilakukan oleh guru adalah memberikan penguatan positif. Dalam pendekatan BCCT ini, anak mengkonstruk pengalaman dan pengetahuannya sendiri, tetapi sangat penting guru memberikan penguatan positif terhadap apa yang anak lakukan. Tujuan dari kegiatan ini agar perilaku menjadi menetap seperti perilaku antri saat di bank, bersikap ramah, tertib dan lain sebagainya.

3. Sambil anak memainkan perannya, guru sembari mengajak anak berdialog. Melakukan dialog adalah kegiatan untuk mengembangkan kemampuan bahasa dan kognitif anak. Dengan berdialog, anak mengasah kemampuan komunikasinya dan menyatakan perasaannya dalam kalimat secara berani.

4. Dalam kegiatan dialog, guru hendaknya dapat memancing pertanyaan. Memancing pertanyaan tujuannya adalah untuk menggugah rasa ingin tahu anak terhadap sesuatu yang baru, mengembangkan keberanian dan kematangan berkomunikasi dan memperkuat kemampuan bahasanya.

5. Mendampingi anak yang menemui kesulitan dengan permainannya;

6. Mengingatkan dan mengenalkan anak dengan kosakata baru;

7. Mengelola kelas agar selalu tertib dan kondusif;

8. Mengingatkan anak akan aturan permainan;

9. Mengingatkan anak akan peran mereka;

10. Memperkuat gagasan dan konsep pengetahuan atau pengalaman;

11. Memberitahukan anak tentang waktu bermain;

12. Meminta anak untuk membereskan main- 
an mereka;

13. Dan yang paling penting adalah guru mengobservasi, mendokumentasi, mencatat dan mengevaluasi perkembangan anak pada saat permainan dilangsungkan.

\section{d. Pijakan Setelah Bermain}

Pijakan setelah bermain adalah kegiatan yang dilakukan oleh guru dan anak sesaat ketika selesai bermain. Anak dan guru kembali duduk melingkar. Dalam kegiatan ini meminta anak menceritakan kembali terhadap apa yang telah mereka lakukan, menanyakan perasaan, memajang hasil karya dan melakukan penguatan positif.

Berdasarkan hasil observasi pada kegiatan pijakan setelah bermain, guru TK Mujahidin Pontianak melakukannya sebagaimana prosedur pendekatan BCCT. Hal tersebut dapat dideskribsikan sebagi berikut:

1. Guru meminta anak untuk membereskan mainan dan menyimpan main pada tempat yang telah ditentukan;

2. Guru melakukan kegiatan Recalling yaitu meminta anak menceritakan kembali pengalaman saat mereka memerankan atau memainkan permainan;

3. Guru menanyakan perasaan anak pada saat kegiatan permainan;

4. Guru kembali memberikan penguatan positif dan;

5. Guru melakukan motivasi akhir terkait permainan dan tema pembelajaran.

\section{E. Keunggulan Model Pembelajaran BCCT}

Jika diterapkan secara prosedural, konsisten dan berkelanjutan, model BCCT memiliki keunggulan untuk melejitkan potensi anak usia dini diantaranya:

1. Model BCCT dapat secara maksimal mengembangkan seluruh potensi AUD yang meliputi aspek kognitif, sosial-emosional, moral spiritual, fisik, visual spasial, natural dan bahasa;

2. Sebagaimana spirit konstruktivisme, BCCT menjadi model pembelajaran yang dapat membuat anak menjadi kreatif dan inovatif;

3. Pembelajaran menjadi menyenangkan dan penuh makna (Joyfull Learning), anak tidak bosan dengan pembelajarannya karena secara reguler bergantian belajar dalam sentra berbeda, anak sangat antusia, apresiatif dan dinamis dalam pembelajaran yang sedang dilangsungkan;

4. Anak mengkonstruksi sendiri pengetahuan dan pengalamannya;

5. Mengajarkan anak mandiri dalam melakukan satu pekerjaan;

6. Mengajarkan anak bertanggung jawab terhadap pekerjaannya;

7. Mengajarkan anak bersosialisasi karena permainan kolaboratif dalam sentra;

8. Guru menjadi fukos dan mendalam menguasai proses pembelajaran satu sentra dimana ia ditugaskan.

\section{F. Kesimpulan dan Rekomendasi}

Berdasarkan hasil penelitian mini dan kajian akademik, maka dapat disimpulkan sebagai berikut:

1. Sentra pendukung pelaksanaan BCCT dapat meliputi: sentra persiapan, sentra bahan alam, sentra seni dan kreativitas, sentra ibadah, sentra balok dan lain sebagainya tergantung kehendak pihak sekolah. Membangun sentra harus disertai dengan konsekuensi melengkapi dengan media permainan yang sesuai;

2. Prosedur pelaksanaan pembelajaran model BCCT meliputi pijakan lingkungan, pijakan sebelum bermain, pijakan saat ber- 
main dan pijakan setelah bermain;

3. Keunggulan model BCCT meliputi: secara maksimal mengembangkan seluruh potensi AUD yang meliputi aspek kognitif, sosial-emosional, moral spiritual, fisik, visual spasial, natural dan bahasa; sebagaimana spirit konstruktivisme, BCCT menjadi model pembelajaran yang dapat membuat anak menjadi kreatif dan inovatif;

Pembelajaran menjadi menyenangkan dan penuh makna (Joyfull Learning), anak tidak bosan dengan pembelajarannya karena secara reguler bergantian belajar dalam sentra berbeda, anak sangat antusia, apresiatif dan dinamis dalam pembelajaran yang sedang dilangsungkan; Anak mengkonstruksi sendiri pengetahuan dan pengalamannya; Mengajarkan anak mandiri dalam melakukan satu pekerjaan;

Mengajarkan anak bertanggung jawab terhadap pekerjaannya; Mengajarkan anak bersosialisasi karena permainan kolaboratif dalam sentra; Guru menjadi fukos dan mendalam menguasai proses pembelajaran satu sentra dimana ia ditugaskan.

Karena kelebihan dan keunggulan BCCT maka dapat direkomendasikan beberapa hal sebagai berikut:

\section{Stake Holder Terkait}

a. Karena pendekatan BCCT dianggap salah satu pendekatan terbaik dalam pembelajaran bagi AUD, maka stake holder terkait dapat membantu melalui kebijakan maupun sokongan finansial lembaga pendidikan pra-sekolah dapat melaksanakan pendekatan. Karena pelaksanaan pendekatan ini memerlukan biaya yang tinggi, seyogyanya intervensi pemerintah dipentingkan untuk dapat merealisasikannya.

b. Mensosialisasikan pendekatan BCCT kepada guru TK/RA melalui seminar atau workshop secara lebih intens.

\section{Lembaga Pendidikan Pra-sekolah}

a. Kepada lembaga pendidikan pra-sekolah seperti TK/RA dapat menginisiasi menggunakan pembelajaran dengan pendekatan BCCT;

b. Mensosialisasikan dengan orang tua anak melaui pertemuan atau seminar agar dapat mendukung untuk melaksanakan BCCT.

\section{DAFTAR RUJUKAN}

B. Hurlock, (2007) Psikologi Perkembangan Suatu Pendekatan Sepanjang Rentang Kehidupan, Eralangga, Jakarta

Gunarsa, Singgih, (1990) Dasar dan Teori Perkembangan Anak, PT. BPK Gunung Mulia, Jakarta

Guntur, Hery Tarigan, (1993) Sastra dan Perkembangan Insani Anak, Penerbit Mimbar Pendidikan bahasa dan Seni, Bandung

Hartati, Sofia, (2005) Perkembangan Belajar Anak Usia Dini, Depdiknas, Jakarta

Jamaris, Martini, (2006) Perkembangan dan Pengembangan Anak Usia Taman Kanak-kanak, Jakarta: Grasindo

Jo Ann Brewer, (2007) Early Childhood Education; Preschool Through Primary Grades

J. Wantah, Maria, (2005) Pengembangan Disiplin dan Pembentukan Moral, Jakarta: Dep. DIKNAS

Kamtani, (2005) Bermain Melalui Gerak dan Lagu di Taman Kanak-kanak, Depdiknas, Jakarta

Masitoh dkk, (2005) Pendekatan Belajar Aktif di Taman Kanak-kanak, Depdiknas, Jakarta 
Nugraha, Ali dan Yeni Rachmawati, Metode Pengembangan Sosial Emosional, Jakarta: Universitas Terbuka, tanpa tahun

Sudrajat, Achmad, Perkembangan Moralitas Anak, http://anakciremai.blogspot.com.

Sujiono, Yuliani Nyrani, Konsep Dasar Pendidikan Anak Usia Dini, Jakarta: Universitas Negeri Jakarta, 2007 dan Bambang Sujiono, (2005) Menu Pembelajaran Anak Usia Dini, Jakarta: Yayasan Citra Pendidikan Indonesia 